\section{Queen Mary College}

QUEAN MARx CoLLege celebrated this week the anniversary of the presentation of a Royal Charter to the College by Her Majesty Queen Mary, the Patron of the College, on December 12, 1934. The proceedings culminated in a reception on the evening of December 16, when the principal of the College, Prof. G. M. Bennett, Prof. J. T. MacGregor-Morris, Miss Florence Rich, and Sir John Russell are being admitted as fellows of the College. The College, which owes so much to the insight and wise guidance of its late principal, Mr. J. L. S. Hatton, and its present principal, Sir Frederick Maurice, occupies a unique position in the scheme of the University of London. Situated a mile and a half east of Aldgate Pump, it provides a university course of training for students drawn in the main from the population of Essex and Middlesex, but not from these regions only, for within its walls are to be found students. coming from all parts of Great Britain and of the Empire.

QueEN MARy CoLlege, which has grown steadily from a small beginning as the Technical School of the People's Palace, has for some time past realized the urgent need for the extension of the housing of its Faculties of Art, Science and Engineering and for the provision of hostels and athletic grounds for its students. It has courageously embarked on a building scheme, under which the Engineering Departments, the Chemistry Department, the Aeronautical Department, and the Botany, Geology and Geography Departments have been extended or reconstructed; new Zoology and Arts Departments have been built, and a high-voltage laboratory, the first of its kind in London, has been equipped. The cost of this completed portion of the programme is some $£ 118,000$, of which $£ 113,000$ has been received or promised. A great deal, however, remains to be accomplished, and the College is now considering the building of a college hall, dining hall and kitchens, the reconstruction of the Students' Union rooms, the rehousing of the administrative offices and an urgently needed extension of the Physies Department. The cost of this last part of the building scheme is estimated at

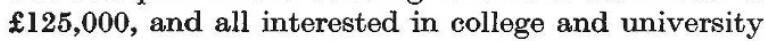
life in London will wish the Governors of Queen Mary College an early success in their attempt to provide a college which shall, in its material equipment, be worthy of the traditions which it has established in its thirty-one years of life as a School of the University of London.

\section{Birkbeck College}

BIRKBeck College, University of London, celebrated on December 7 its 115 th anniversary with an eloquent oration on "Ends and Means"' by Sir Richard Livingstone, president of Corpus Christi College, Oxford. The Foundation oration dealt with the underlying principles of morality in individual and social intercourse in contrast with the present unrest in world affairs. In his report, which was followed by the presentation of graduates, Dr. George Senter, principal of the College, mentioned various details about its progress, the plan for moving it to the Bloomsbury site, the distinctions gained by the staff, and the activities of the various College societies. During the last academic year, there were 971 students registered, 122 having graduated. Statistics show that 430 students were teachers, 176 clerks and 132 chemists. Considerable progress was made during the year with the plans for new College buildings on the Bloomsbury site. Towards the end of the session, instructions were given for the clearance of the site, and it was expected that the detailed plans would be submitted soon to the Governors. A notable appointment to the academic staff was that of Prof. J. D. Bernal who succeeded Prof. P. M. S. Blackett in the chair of physies. Prof. Bernal's work is mainly concerned with structural investigations by means of X-rays, and is of great interest to chemists and biologists as well as to physicists.

\section{German Native Policy and Racial Theory}

Discussion of German colonial claims will be clarified by a statement of the policy which would be applied in native administration under racial doctrine, appearing in an official publication of the National Socialist Party-"The Colonial Question and Racial Thought" by Dr. Günther Hecht, an expert of the party on racial problems. As might be anticipated, the principle of segregation, it would appear from a summary of the provisions by the Berlin correspondent of The Times in the issue of December 12, is to be applied stringently, and any attempt to Europeanize or divorce the native from his culture is abrogated : he will neither be baptized, nor will his equality with Europeans be preached. No native will be allowed to leave the German colonies for Europe as either servant, worker, soldier or student, but on the other hand, coloured people will be allowed their full rights of existence in their own homeland, and no more will be demanded from them than they can achieve. No native will be allowed to become a German citizen, but they will nevertheless possess more rights than have been merely promised to them in other colonies. No European matter will be taught in native schools, lest Europe should be presented to them as the peak of cultural development and they should lose faith in their own powers. Local culture, therefore, will be fostered, but side by side with it there will be an introduction to an understanding of European civilization. In principle, higher schools and universities will be closed to natives. Without entering into extended comment on the principles of this policy, beyond noting a commendable adherence to the development of the native through his own culture, it may be questioned what opportunities will be afforded for development towards that selfdetermination, however remote it may be and whatever its form, which has been formulated as the end of native administration under mandatory policy.

\section{Systematics in General Biology}

THE annual general meeting of the Association for the Study of Systematies in General Biology was held in the rooms of the Linnean Society, Burlington 
House, Piccadilly, London, on December 15. The inaugural meeting of this newly established association was referred to in Nature of July 24, 1937, p. 163. At its inception, 53 biologists joined the Association, and since then the membership has increased to 162. The aims of the Association, among others, are : to study the bases and practical aims of taxonomy; to examine criteria employed in defining species and other systematic categories; to consider any modification of existing classification in the light of eytogenetic, ecological, physiological, embryological, biochemical and palæontological data ; to press for increased attention to taxonomy in museums and other institutions; to organize research; to aid the production of handbooks on British animals and plants, and eventually to produce a British Fauna and Flora on uniform biological lines; to investigate methods of teaching systematics; to promote co-operation between workers in different branches of biology on problems of taxonomic interest. The Taxonomic Principles Committee has already considered several important problems, and has decided to prepare an index of all terms which have been used to designate groups below the rank of species. This should prove of value, especially to young research workers in taxonomy. The Committee on Comparative Systematics has examined the sources from which data for research on variability and other problems may be drawn. The Research Committee has initiated or assisted in the launching of twelve lines of research, and a list of institutions where such work may be done has been prepared. Work has been started on a book on the anatomy of Dicotyledons. The Committee on Handbooks is now compiling a review of existing taxonomic literature on the British flora and fauna. The provision of a check list of the British flora and fauna is being dealt with in collaboration with the Association of British Zoologists. Cheap systematic handbooks are also being considered.

The Committee for Co-ordinating the Work of Natural History Societies has been aided in its exacting task by the British Association. The pioneer work of these various committees is commendable, and all biologists, whether directly interested in systematics or not, will be grateful for the results of their work. Various publications, such as articles in NATURE and Chronica Botanica, have been sponsored by the Association, and others are projected. Discussions and symposia on taxonomic subjects have been supported by the Association at meetings of the British Association and of the Linnean, Zoological and Genetical Societies. The Association has no constitution yet, but it has since worked with enthusiasm. It is considered that with a minimum membership of five hundred, each member paying the modest sum of $£ 1$ for lifemembership, the Association could achieve all its aims. We hope that this enro'ment will be achieved and even exceeded, for the Association has, in a very short time, showed that it is providing an essential service to biology, and considering its present projects, its usefulness will certainly continue to increase. Not only specialized systematists but also all other biologists would prove useful to this Association, which clearly deserves all the support it can get. Information concerning the Association can be obtained from either Mr. J. S. L. Gilmour, Royal Botanic Gardens, Kew, Surrey, or Mr. H. W. Parker, British Museum (Natural History), South Kensington, London, S.W.7.

\section{Palæolithic Finds in Bulgaria}

Dr. Dorothy Garrod's account of her recent excavation of the cave of Batcho Kiro, near Drevono, in Bulgaria, given before the Society of Antiquaries of London on December 8, adds a link of no little importance to the chain of evidence of the distribution of cultures of the later periods of the palæolithic age in eastern Europe and adjacent regions. Dr. Garrod's excavations were carried out in the summer of 1938 , when she had the assistance of $\mathrm{Mr}$. James Gaul and Mr. Bruce Howe of Harvard University, by permission of the Bulgarian Government and with the cooperation of the National Museum of Sophia. The cave is very large with an intricate system of corridors running at least a kilometre into the rock. Flint implements had already been discovered here in association with bones of the cave bear by a local engineer. The present excavations were confined in the main to the principal chamber; and here for the first time in Bulgaria a stratified sequence of palæolithic deposits has been found. At the bottom of the section was a Mousterian level, in which the implements were made chiefly from pebbles of volcanic rock from a stream near by. Above this level were layers of deposits belonging to the Upper Palæolithic, in which the industries were more or less of Aurignacian type, and the implements were made of flint. They were associated with animal bones, among which were cave bear, cave hyena, and in the lowest levels woolly rhinoceros. These levels, corresponding to others of the same kind in other parts of Europe, are to be assigned to the last stage of the Quaternary Ice Age.

\section{Prehistoric "Harpoon" from Scotland}

A REMARKABLE barbed point of red deer antler found in the bed of the River Irvine below Shewalton Sands, Ayrshire, was described by Mr. A. D. Lacaille at a meeting of the Society of Antiquaries of Scotland in Edinburgh on December 12. The point, which may have been part of a harpoon or multi-pronged fish-spear, is believed to be the largest prehistoric point of its kind as yet recorded in the British Isles. It measures $75 \frac{5}{8}$ inches long, and is rhombic in section. It has five pairs of barbs. A groove appears on each side of a pronounced mid-rib at the tip. It has been skilfully fashioned, evidently by stone tools. The dating of the point is uncertain ; but it is conjectured that it was made by settlers on Shewalton Moor, a locality rich in prehistoric and other antiquities. Both its form in section and the grooves mark a considerable technical advance on the Azilian type of barbed harpoon. Nevertheless, the Shewalton point, it is indicated, bears a general resemblance 